\title{
Organization Name
}

National Cancer Institute

\section{Source}

National Cancer Institute. Organization Name. NCI Thesaurus. Code C93874.

A textual identifier for an organization. 